\title{
Comparison of the Electrical Properties of PERC Approach Applied to Monocrystalline and Multicrystalline Silicon Solar Cells
}

\author{
Enyu Wang, ${ }^{1,2}$ He Wang, ${ }^{1}$ and Hong Yang ${ }^{1}$ \\ ${ }^{1}$ MOE Key laboratory for Nonequilibrium Synthesis and Modulation of Condensed Matter, School of Science, \\ Xian Jiaotong University, Xian 710049, China \\ ${ }^{2}$ Lu'an Photovoltaics Technology Co., Ltd., Changzhi 046000, China
}

Correspondence should be addressed to Hong Yang; hongy126@126.com

Received 22 June 2016; Accepted 14 September 2016

Academic Editor: Simona Binetti

Copyright (C) 2016 Enyu Wang et al. This is an open access article distributed under the Creative Commons Attribution License, which permits unrestricted use, distribution, and reproduction in any medium, provided the original work is properly cited.

\begin{abstract}
At present, the improvement in performance and the reduction of cost for crystalline silicon solar cells are a key for photovoltaic industry. Passivated emitter and rear cells are the most promising technology for next-generation commercial solar cells. The efficiency gains of passivated emitter and rear cells obtained on monocrystalline silicon wafer and multicrystalline silicon wafer are different. People are puzzled as to how to develop next-generation industrial cells. In this paper, both monocrystalline and multicrystalline silicon solar cells for commercial applications with passivated emitter and rear cells structure were fabricated by using cost-effective process. It was found that passivated emitter and rear cells are more effective for monocrystalline silicon solar cells than for multicrystalline silicon solar cells. This study gives some hints about the industrial-scale mass production of passivated emitter and rear cells process.
\end{abstract}

\section{Introduction}

Over past decades, photovoltaic market was dominated by standard crystalline silicon solar cells which were based on boron-doped crystalline silicon wafers with processes of phosphorus diffusion, silicon nitride antireflection coatings on front side, screen-printed silver past on front side, and aluminum paste on rear side forming a back surface field (Al-BSF). In recent years, the continued bleakness of photovoltaic industry has forced manufacturers to further increase conversion efficiency and reduce manufacturing costs so as to survive in escalated fierce competition [1-3]. At present, passivated emitter and rear cells (PERC), which were firstly reported in 1989 , are attracting more and more attentions [4-6]. In PERC structure, a dielectric layer was fabricated on the rear side of solar cells replacing aluminium back surface field. This was advantageous to reduce the rear surface recombination and increase internal reflection on rear surface. Consequently, higher efficiency solar cells could be obtained.
At present, various methods have been reported to prepare PERC cells and some of them could achieve very good efficiency [7]. In these literatures, aluminum oxide is the most popular material for rear passivation layer. It could provide high-quality passivation [8]. However, the fabrication of aluminum oxide is not very cost-effective and is limited in lab conditions. Therefore, silicon oxynitride, which can be easily fabricated using PECVD, was used for rear passivation layer. This design is a new structure of PERC cells. Its process has high similarity with standard Al-BSF process. It can be easily integrated to standard Al-BSF production lines and is very suitable for mass production. Most of equipment for AlBSF could be utilized and only one or two new machines are required.

Moreover, there are few researchers to report the comparison of PERC with silicon oxynitride applied to monocrystalline silicon solar cells $(\mathrm{Cz}-\mathrm{Si})$ and multicrystalline silicon solar cells (Mc-Si) [2]. People are puzzled as to how to develop next-generation industrial solar cells. In this paper, both $\mathrm{Cz}$-Si and $\mathrm{Mc}-\mathrm{Si}$ solar cells with PERC structure were 
TABLE 1: Process sequence of Al-BSF solar cells.

\begin{tabular}{|c|c|}
\hline Step number & Process description \\
\hline 1 & Acid or alkaline texturing \\
\hline 2 & $\mathrm{POCl}_{3}$ diffusion \\
\hline 3 & PSG removing \& edge isolation \\
\hline 4 & $\mathrm{SiN}_{x}: \mathrm{H}$ ARC on front side \\
\hline 5 & Screen-printing and metallization \\
\hline
\end{tabular}

TABLE 2: Process sequence of PERC solar cells.

\begin{tabular}{|c|c|}
\hline Step number & Process description \\
\hline 1 & Acid or alkaline texturing \\
\hline 2 & $\mathrm{POCl}_{3}$ diffusion \\
\hline 3 & PSG removing \& edge isolation \\
\hline 4 & $\mathrm{SiN}_{x}: \mathrm{H}$ ARC on front side \\
\hline 5 & Rear surface polishing \\
\hline 6 & Rear passivation layer \\
\hline 7 & Rear laser opening \\
\hline 8 & Screen-printing and metallization \\
\hline
\end{tabular}

fabricated by using cost-effective process. It was found that PERC approach was more effective for $\mathrm{Cz}-\mathrm{Si}$ and $\mathrm{Mc}$-Si solar cells. This study gives some hints about the industrial-scale mass production of PERC process.

\section{Experimental Methods}

2.1. Cells Fabrication. Silicon oxynitride (hereinafter referred to as $\mathrm{SiO}_{x} \mathrm{~N}_{\gamma}: \mathrm{H}$ ) and silicon nitride (hereinafter referred to as $\left.\mathrm{SiN}_{x}: \mathrm{H}\right)$ film stacks were selected as rear passivation layer. $\mathrm{SiO}_{x} \mathrm{~N}_{y}: \mathrm{H}$ layers contain a large amount of hydrogen which can be used to saturate the dangling bonds on wafer surface, resulting in good passivation. Oxygen participation can form $\mathrm{Si}-\mathrm{O}$ bond on surface prior to $\mathrm{Si}-\mathrm{H}$ bond. This is very helpful for interface stability and reduces the density of interface states [9]. Moreover, the $\mathrm{SiO}_{x} \mathrm{~N}_{y}: \mathrm{H}$ film capped by the $\mathrm{SiN}_{x}: \mathrm{H}$ film could enhance the heat endurance of the film stacks [10].

The $156 \mathrm{~mm} \times 156 \mathrm{~mm}\left(238.95 \mathrm{~cm}^{2}\right)$ boron-doped industrial $\mathrm{Cz}$-Si wafers and the $156 \mathrm{~mm} \times 156 \mathrm{~mm}\left(243.36 \mathrm{~cm}^{2}\right)$ boron-doped industrial $\mathrm{Mc}-\mathrm{Si}$ wafers were used for our experiments. The wafers were sliced by conventional wiresaw technique, with thickness of about $195 \mu \mathrm{m}$ and resistivity of $1-3 \Omega \cdot \mathrm{cm}$. Table 1 shows process sequence of Al-BSF solar cells; Table 2 shows process sequence of PERC solar cells. Initially, the $\mathrm{Cz}-\mathrm{Si}$ and $\mathrm{Mc}-\mathrm{Si}$ wafers were, respectively, textured by standard alkaline process with $\mathrm{NaOH}$ solutions and by standard acid process with $\mathrm{HF} / \mathrm{HNO}_{3}$ solutions. The textured wafers were then diffused using $\mathrm{POCl}_{3}$ as the dopant source to form an emitter with a suitable sheet resistance, respectively. The junction depth was about $0.4 \mu \mathrm{m}$. After $\mathrm{POCl}_{3}$ diffusion, the phosphosilicate glass (PSG) removal and edge isolation were performed by wet chemical etching. Silicon nitride as antireflection coating was manufactured by plasma enhanced chemical vapor deposition using silane and ammonia on front side. The refractive index of the films was about 2.10 at a wavelength of $632.8 \mathrm{~nm}$. Thereafter, rear surface polishing was carried out in a wet etching slot by alkaline solutions. The front textured surface would not be damaged because of silicon nitride film playing a role of mask. The polishing step is indispensable because the quality of rear passivation was hugely influenced by rear surface roughness [11]. After polishing, silicon oxynitride and silicon nitride film stacks were deposited on rear surface by plasma enhanced chemical vapor deposition using silane, ammonia, and nitrous oxide as precursor. The refractive index of silicon oxynitride was about 1.8 and that of silicon nitride was about 2.2. Then, the rear dielectric film stacks were locally ablated by laser to form local openings for rear metallic contact. The laser opening pattern was parallel lines perpendicular to the front busbars, which act like rear fingers. The line width was about $70 \mu \mathrm{m}$ and the line distance was about $1.2 \mathrm{~mm}$. Finally, metallization process was carried out in a conventional way. Silver and aluminium paste were screen-printed on front and rear surface of wafers, which then formed electric contact of solar cells through a fast firing process.

2.2. Measurement and Comparison. The aim of this research is to compare the gains of PERC approach applied to $\mathrm{Cz}-\mathrm{Si}$ wafers and Mc-Si wafers. Therefore, standard Al-BSF cells prepared on $\mathrm{Cz}-\mathrm{Si}$ and $\mathrm{Mc}-\mathrm{Si}$ wafers were simultaneously fabricated as reference groups. The wafers for Al-BSF and PERC were artificially randomized into two groups in order to prevent wafer qualities influencing fair comparison.

The testing and sorting of solar cells were performed by Berger testing system under Standard Test Conditions $\left(25^{\circ} \mathrm{C}\right.$, AM1.5, and $1000 \mathrm{~W} / \mathrm{m}^{2}$ ). The calibration cell was certificated by Fraunhofer ISE. The refractive index of films was measured using ellipsometer. The IQE was measured by WT-2000. Figure 1 shows the experimental sample of $\mathrm{Cz}-\mathrm{Si}$ solar cells with PERC structure. The experimental sample of Mc-Si solar cells with PERC structure is indicated in Figure 2.

\section{Results and Discussion}

3.1. Monocrystalline Silicon Solar Cells with PERC Structure. The electrical parameters of $\mathrm{Cz}-\mathrm{Si}$ solar cell with Al-BSF and PERC structure are indicated in Table 3. These were average values, including efficiency, $\eta$, open-circuit voltage, $V_{\text {oc }}$, short-circuit current, $I_{\mathrm{sc}}$, fill factor, FF, series resistance, $R_{s}$, shunt resistance, $R_{\text {sh }}$, and reverse current, $I_{\text {rev }}$, under $12 \mathrm{~V}$ reverse bias.

The open-circuit voltage was greatly improved from $0.641 \mathrm{~V}$ to $0.650 \mathrm{~V}$. The results indicated that $\mathrm{SiO}_{x} \mathrm{~N}_{y}: \mathrm{H} /$ $\mathrm{SiN}_{x}: \mathrm{H}$ film stacks were effective to provide rear passivation of good quality. The short-circuit current was also increased from $9.12 \mathrm{~A}$ to $9.52 \mathrm{~A}$. This must be mainly attributed to rear dielectric layer acting as a rear reflector to enhance internal light reflection and improve the long wavelength response. The internal quantum efficiency (IQE) was measured and confirmed in Figure 3. Data were measured for wavelength from $300 \mathrm{~nm}$ to $1200 \mathrm{~nm}$ to compare Al-BSF and PERC approaches. The spectral response was similar in medium and short wavelength, while the response of PERC was better above about $900 \mathrm{~nm}$. This would result in higher short-circuit current and be beneficial to efficiency. A little difference of FF 

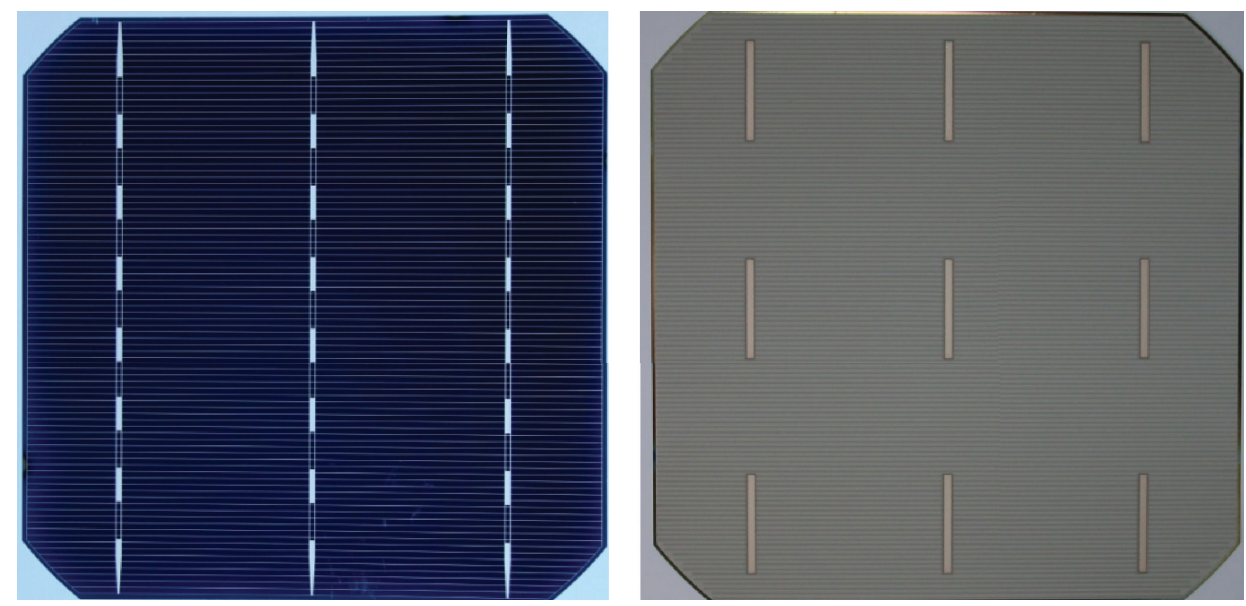

FIGURE 1: The experimental sample of Cz-Si solar cells with PERC structure.
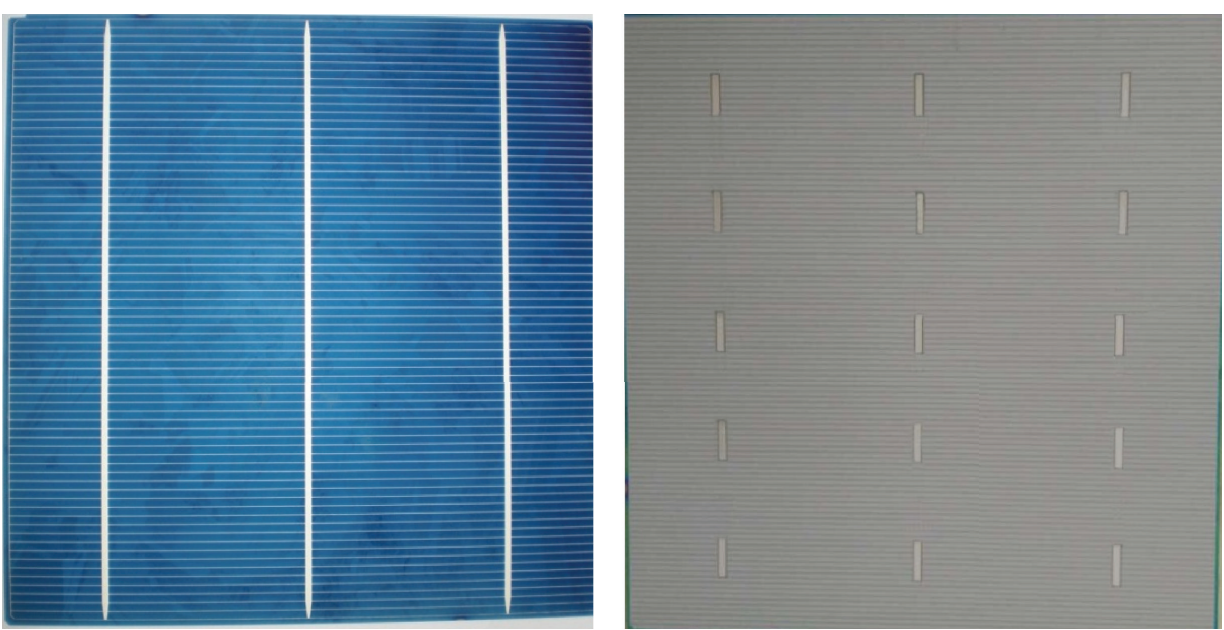

FIGURE 2: The experimental sample of Mc-Si solar cells with PERC structure.

TABLE 3: Cz-Si solar cells parameters with Al-BSF and PERC structure.

\begin{tabular}{lccccccc}
\hline Cell type & $\eta(\%)$ & $V_{\text {oc }}(\mathrm{V})$ & $I_{\mathrm{sc}}(\mathrm{A})$ & $\mathrm{FF}(\%)$ & $R_{s}(\Omega)$ & $R_{\text {sh }}(\Omega)$ & $I_{\text {rev }}(\mathrm{A})$ \\
\hline Al-BSF & 19.55 & 0.641 & 9.12 & 79.92 & 0.0021 & 450.3 \\
PERC & 20.41 & 0.650 & 9.52 & 78.81 & 0.0029 & 637.5 & 0.05 \\
\hline
\end{tabular}

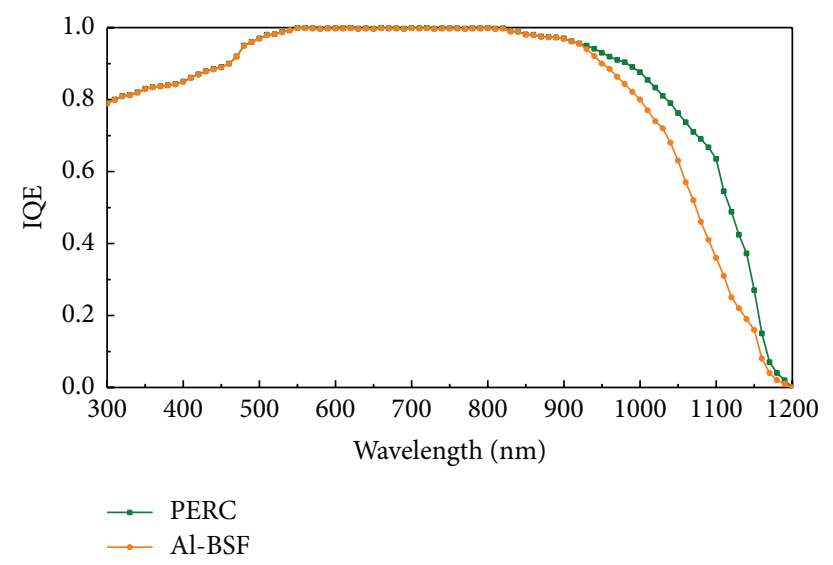

FIGURE 3: The internal quantum efficiency of Cz-Si silicon solar cells with Al-BSF and PERC structure. 


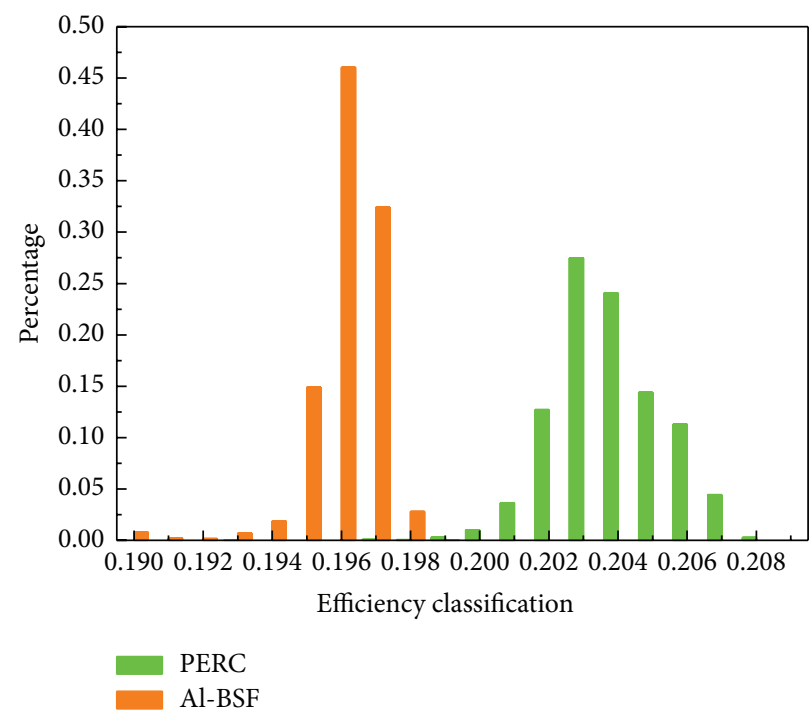

FIgURE 4: Efficiency distribution of Cz-Si solar cells with Al-BSF and PERC structure.

TABLE 4: Mc-Si cell parameters of Al-BSF and PERC.

\begin{tabular}{lccccccc}
\hline Cell type & $\eta(\%)$ & $V_{\text {oc }}(\mathrm{V})$ & $I_{\mathrm{sc}}(\mathrm{A})$ & $\mathrm{FF}(\%)$ & $R_{s}(\Omega)$ & $R_{\text {sh }}(\Omega)$ & 318.5 \\
\hline Al-BSF & 18.46 & 0.629 & 8.98 & 79.54 & 0.0022 & 0.08 \\
PERC & 18.61 & 0.633 & 9.24 & 77.45 & 0.0036 & 87.9 & 2.92 \\
\hline
\end{tabular}

was due to slightly higher series resistance $R_{s}$ resulting from smaller rear contact area compared with Al-BSF.

The average efficiency gain of PERC was about $0.9 \%$ absolutely, and the highest efficiency achieved is $20.83 \%$, although the fill factor was a little lower. This is probably owing to local contact on rear side. The distribution of efficiency was shown in Figure 4.

3.2. Multicrystalline Silicon Solar Cells with PERC Structure. The electrical parameters of Mc-Si solar cells with Al-BSF and PERC structure were shown in Table 4 . The average efficiency of PERC was only increased from $18.46 \%$ to $18.61 \%$. The efficiency gain was insignificant compared with PERC approach applied to $\mathrm{Cz}$-Si wafers. The internal quantum efficiency (IQE) was similar to Cz-Si solar cells. The distribution of efficiency, which was shown in Figure 5, has relatively higher dispersion than that of PERC approach applied to $\mathrm{Cz}-\mathrm{Si}$ wafers. And the proportion of poor efficiency PERC cells is higher than that of Al-BSF cells. Both $V_{\mathrm{oc}}$ and $I_{\mathrm{sc}}$ were increased a little, and the efficiency gain is smaller than that applied to $\mathrm{Cz}$-Si wafers. What is worse, the fill factor loss became larger. The low fill factor resulted from the bad contact, which could be confirmed by higher series resistance and lower shunt resistance. The results must be attributed to the different polishing effects of $\mathrm{Cz}$-Si wafers and $\mathrm{Mc}-\mathrm{Si}$ wafers. It was very difficult to polish Mc-Si wafers uniformly by alkaline solutions because of isotropy. Therefore, the rear surface of Mc-Si wafers could not be as smooth as that of $\mathrm{Cz}-\mathrm{Si}$ wafers. The rough surface would lead to spiking of aluminum paste through $\mathrm{SiO}_{x} \mathrm{~N}_{y}: \mathrm{H} / \mathrm{SiN}_{x}: \mathrm{H}$ film stacks to create poor contact [12]. Moreover, the poor contact led to the reverse current, which could be found in Table 4. An

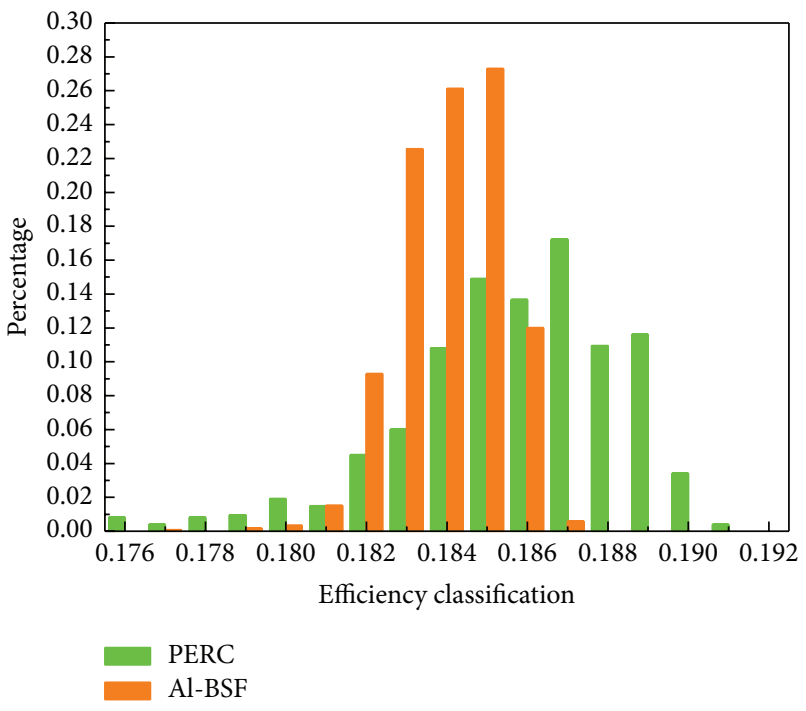

FIGURE 5: Efficiency distribution of Mc-Si solar cells with Al-BSF and PERC structure.

electroluminescence image under reverse bias was shown in Figure 6. Many points of electricity leakage can be seen in this picture. This was also harmful to $V_{\mathrm{oc}}$ and $I_{\mathrm{sc}}$.

The combination of all these factors above resulted in only about $0.15 \%$ efficiency gain of PERC approach applied to McSi wafers.

3.3. Annealing Process. The effect of annealing process to improve surface passivation quality was demonstrated in 
TABLE 5: Efficiency improvement of Cz-Si PERC after annealing.

\begin{tabular}{lccccc}
\hline Cell type & $\eta(\%)$ & $V_{\text {oc }}(\mathrm{V})$ & $I_{\text {sc }}(\mathrm{A})$ & FF $(\%)$ & $R_{s}(\Omega)$ \\
\hline Cz-Si PERC with annealing & 20.59 & 0.653 & 9.58 & 78.77 & 0.0028 \\
Cz-Si PERC without annealing & 20.39 & 0.649 & 9.53 & 78.65 & 0.0029 \\
\hline
\end{tabular}

TABLE 6: Efficiency improvement of Mc-Si PERC after annealing.

\begin{tabular}{lccccccc}
\hline Cell type & $\eta(\%)$ & $V_{\text {oc }}(\mathrm{V})$ & $I_{\text {sc }}(\mathrm{A})$ & FF $(\%)$ & $R_{s}(\Omega)$ & $R_{\text {sh }}(\Omega)$ & $I_{\text {rev }}(\mathrm{A})$ \\
\hline Mc-Si PERC with annealing & 18.69 & 0.635 & 9.23 & 77.64 & 0.0034 & 98.7 & 2.78 \\
Mc-Si PERC without annealing & 18.60 & 0.633 & 9.22 & 77.55 & 0.0036 & 95.6 & 2.62 \\
\hline
\end{tabular}

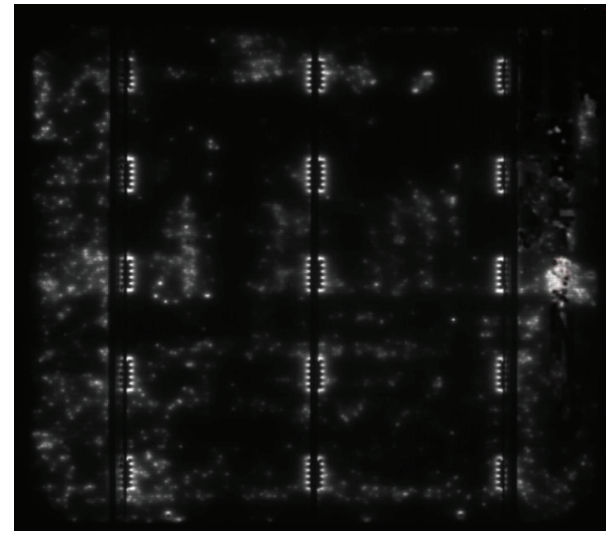

Figure 6: EL image of Mc-Si solar cells With PERC structure under reverse bias.

some researches [13]. Hydrogen existed in dielectric layers in the form of $\mathrm{Si}-\mathrm{H}$ or $\mathrm{N}-\mathrm{H}$ bond. These bonds could be fractured at heating condition and produced a mass of hydrogen atoms which would diffuse into silicon wafers by thermal drive. And then defect states on silicon surface could be saturated, decreasing the quantities of recombination centers. Besides, the annealing process could dissolute the unstable phosphorus-oxygen complexes near the front surface in emitter. It would reduce the quantity of inactive phosphorus and had a positive effect to improve the emitter's recombination activity [14]. Therefore, an annealing process for both Cz-Si and Mc-Si was added after rear passivation layer. In this step, the wafers were properly heated up to about $700^{\circ} \mathrm{C}$ in the atmosphere of nitrogen. After staying for about 15 minutes, they were slowly cooled down and unloaded. And the average efficiency of solar cells was further increased by about $0.2 \%$, which was shown in Table 5 .

However, the improvement of annealing applied to Mc$\mathrm{Si}$ was not as effective as that applied to $\mathrm{Cz}-\mathrm{Si}$. The cell parameters were shown in Table 6 . The efficiency gain was only about $0.09 \%$. The annealing process was not helpful to decrease reverse current for Mc-Si PERC.

\section{Conclusions}

In this paper, the commercial Cz-Si and Mc-Si solar cells with PERC structure were fabricated using $\mathrm{SiO}_{x} \mathrm{~N}_{y}: \mathrm{H} / \mathrm{SiN}_{x}: \mathrm{H}$ film stacks as rear passivation layer. The average gain of $\mathrm{Cz}-\mathrm{Si}$
PERC was as high as $0.9 \%$. And the annealing process was also helpful for $\mathrm{Cz}$-Si PERC, obtaining about $0.2 \%$ further improvement. However, PERC approach applied to Mc-Si was not as effective as that applied to Cz-Si. The efficiency gain was only about $0.15 \%$. This was very limited and much less than that of $\mathrm{Cz}$-Si. Moreover, Mc-Si PERC had electricity leakage problem, which would lead to serious degradation and be very harmful to device lifetime. So PERC approach applied to Mc-Si is not cost-effective at present. This was because it was very difficult to get enough smooth surface for Mc-Si wafers using alkaline polishing. The reason for not using acid polishing was that it would make process flow too complex and inefficient. Acid, which was usually $\mathrm{HF} / \mathrm{HNO}_{3}$, could damage silicon nitride, emitter, and rear passivation layer. Some additional steps have to be carried out to avoid this. This adds complexity of process. So it is very important to improve rear contact of Mc-Si PERC before commercialization.

\section{Competing Interests}

The authors declare that they have no competing interests.

\section{Authors' Contributions}

Enyu Wang and He Wang contributed equally to this work.

\section{Acknowledgments}

The authors would like to acknowledge the support of National Key Technology Research and Development Program of the Ministry of Science and Technology of China (Grant no. 2015BAA09B01). This study was also supported by the Natural Science Foundation of China (Grant nos. 61274050 and 61376067).

\section{References}

[1] M. Kim, S. Park, and D. Kim, "Highly efficient PERC cells fabricated using the low cost laser ablation process," Solar Energy Materials and Solar Cells, vol. 117, pp. 126-131, 2013.

[2] Y. Gassenbauer, K. Ramspeck, B. Bethmann et al., "Rear-surface passivation technology for crystalline silicon solar cells: a versatile process for mass production," IEEE Journal of Photovoltaics, vol. 3, no. 1, pp. 125-130, 2013. 
[3] H. Yang and H. Wang, "Performance analysis of crystalline silicon solar modules with the same peak power and the different structure," Clean Technologies and Environmental Policy, vol. 13, no. 3, pp. 527-533, 2011.

[4] A. W. Blakers, A. Wang, A. M. Milne, J. Zhao, and M. A. Green, “22.8\% Efficient silicon solar cell," Applied Physics Letters, vol. 55, no. 13, pp. 1363-1365, 1989.

[5] M. A. Green, "The Passivated Emitter and Rear Cell (PERC): from conception to mass production," Solar Energy Materials and Solar Cells, vol. 143, article 7819, pp. 190-197, 2015.

[6] Z. Wang, P. Han, H. Lu et al., "Advanced PERC and PERL production cells with $20.3 \%$ record efficiency for standard commercial p-type silicon wafers," Progress in Photovoltaics: Research and Applications, vol. 20, no. 3, pp. 260-268, 2012.

[7] A. Richter, Aluminum Oxide for the Surface Passivation of High Efficiency Silicon Solar Cells: Technology and Advanced Characterization, Fraunhofer, Stuttgart, Germany, 2015.

[8] L. Q. Zhu, Y. H. Liu, H. L. Zhang, H. Xiao, and L. Q. Guo, "Atomic layer deposited $\mathrm{Al}_{2} \mathrm{O}_{3}$ films for anti-reflectance and surface passivation applications," Applied Surface Science, vol. 288, pp. 430-434, 2014.

[9] B. Hallam, B. Tjahjono, and S. Wenham, "Effect of PECVD silicon oxynitride film composition on the surface passivation of silicon wafers," Solar Energy Materials and Solar Cells, vol. 96, no. 1, pp. 173-179, 2012.

[10] N. Brinkmann, D. Sommer, G. Micard, G. Hahn, and B. Terheiden, "Electrical, optical and structural investigation of plasmaenhanced chemical-vapor-deposited amorphous silicon oxynitride films for solar cell applications," Solar Energy Materials and Solar Cells, vol. 108, pp. 180-188, 2013.

[11] J. Seiffe, L. Gautero, M. Hofmann et al., "Surface passivation of crystalline silicon by plasma-enhanced chemical vapor deposition double layers of silicon-rich silicon oxynitride and silicon nitride," Journal of Applied Physics, vol. 109, no. 3, Article ID 034105, 2011.

[12] C. Kranz, S. Wyczanowski, S. Dorn et al., "Impact of the rear surface roughness on industrial-type PERC solar cells," in Proceedings of the 27th European Photovoltaic Solar Energy Conference, pp. 557-560, Frankfurt, Germany, September 2012.

[13] M. Richter, M. Zimmer, J. Rentsch, Y. Friedekind, and A. Fischer, "Characterization of the rear surface roughness of wet chemical polished industrial-type solar cells," in Proceedings of the 40th IEEE Photovoltaic Specialist Conference (PVSC '14), pp. 1238-1243, June 2014.

[14] D.-Y. Lee, H.-H. Lee, J. Yong Ahn et al., "A new back surface passivation stack for thin crystalline silicon solar cells with screen-printed back contacts," Solar Energy Materials \& Solar Cells, vol. 95, no. 1, pp. 26-29, 2011. 

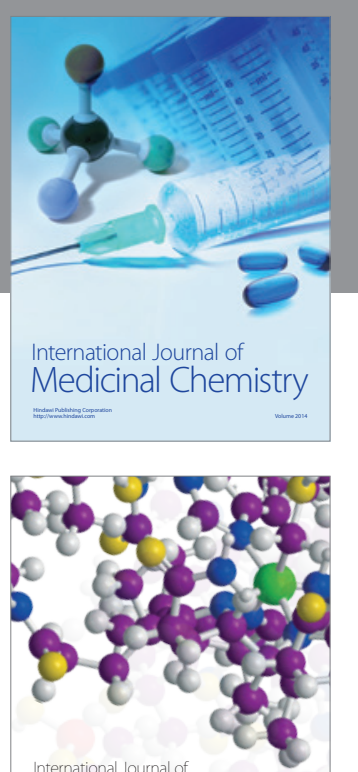

Carbohydrate Chemistry

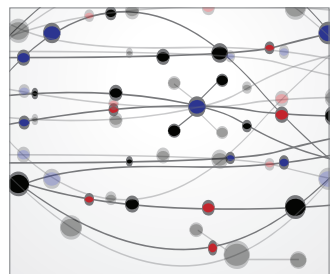

The Scientific World Journal
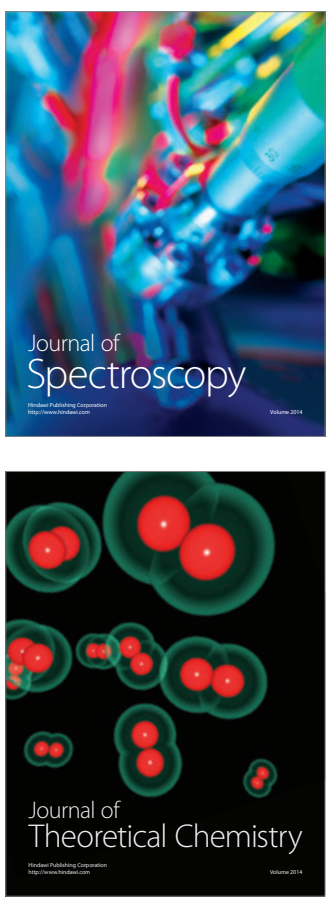
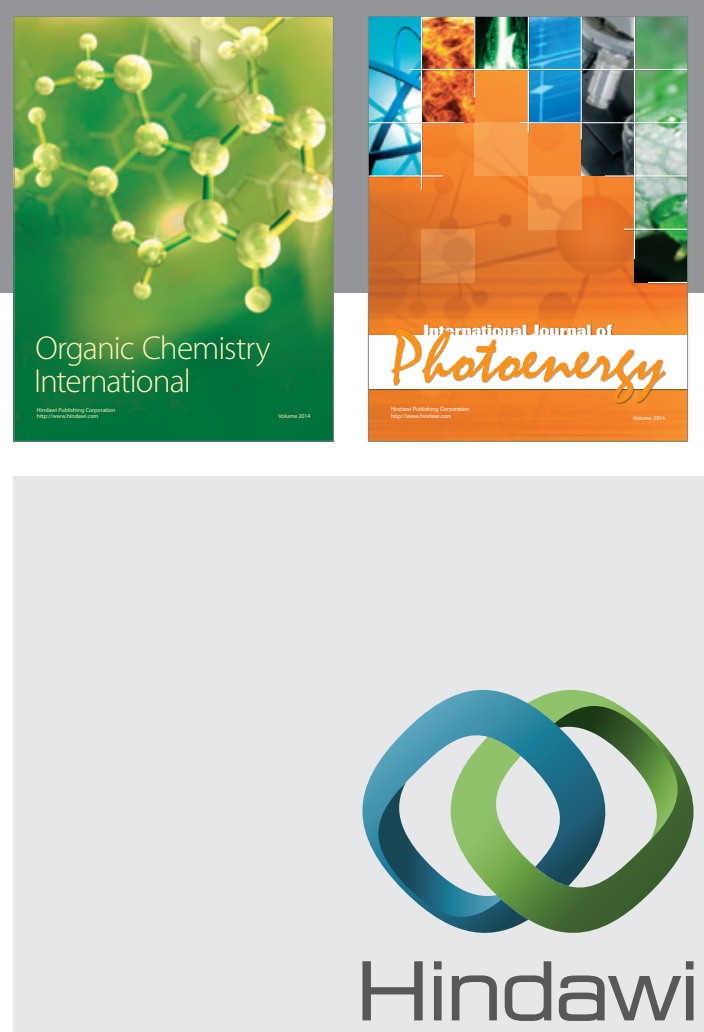

Submit your manuscripts at

http://www.hindawi.com

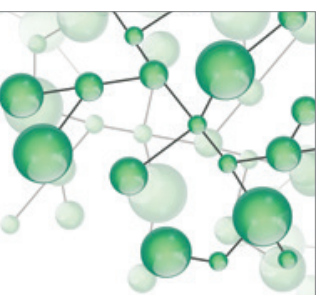

International Journal of

Inorganic Chemistry

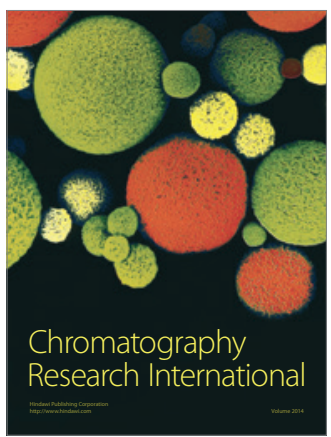

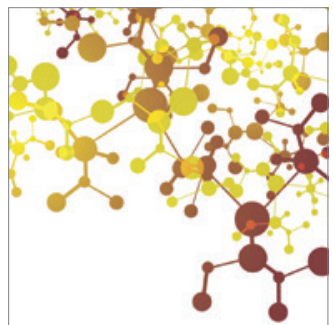

Applied Chemistry
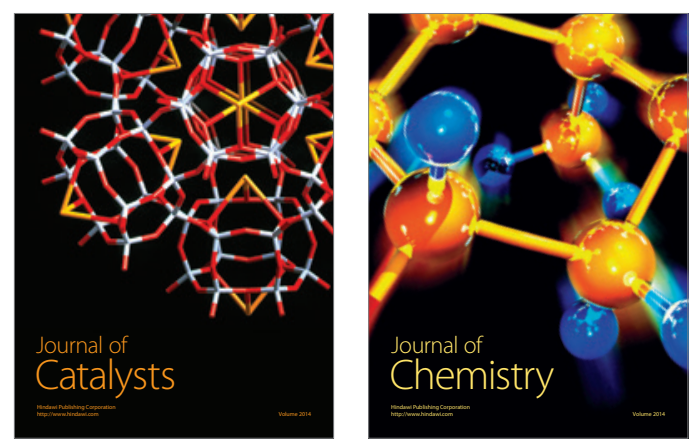
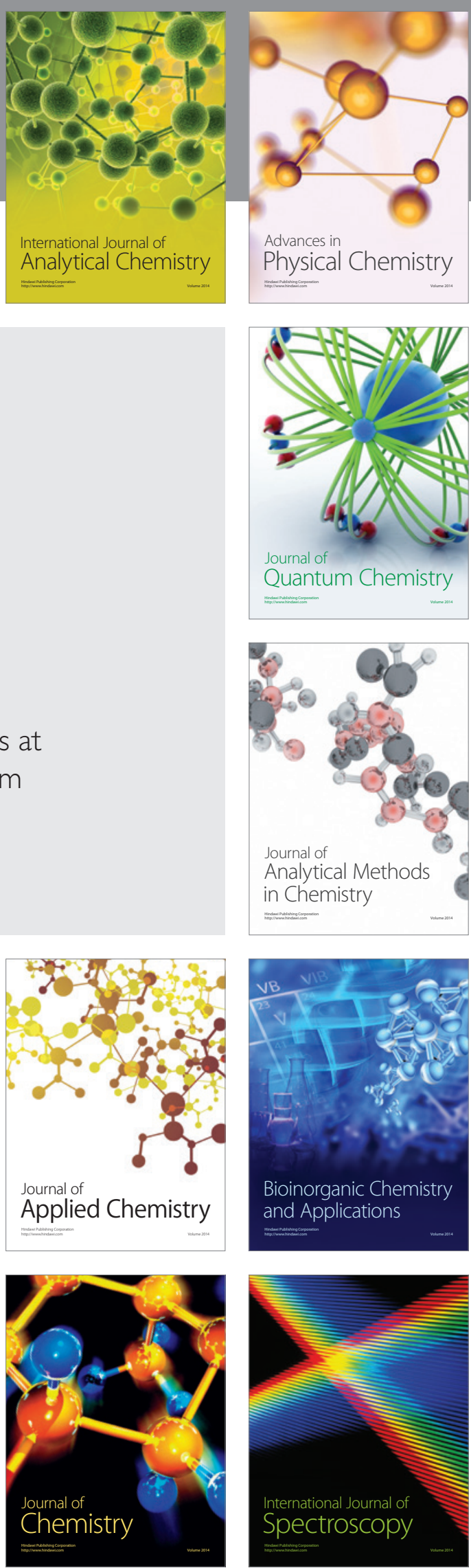